\title{
LYSOLECITHIN AND HEMOLYTIC ANEMIA. THE SIGNIFICANCE OF LYSOLECITHIN PRODUCTION IN THE DIFFER- ENTIATION OF CIRCULATING AND STAGNANT BLOOD ${ }^{1}$
}

\author{
By KARL SINGER \\ (From the Hematology Laboratory, Boston Dispensary and the Joseph H. Pratt \\ Diagnostic Hospital, Boston)
}

(Received for publication October 4, 1940)

Considerations regarding the etiology of hemolytic jaundice are inextricably bound up with the presence of spherocytosis and the associated increase in hypotonic saline fragility, and the effect of splenectomy in the amelioration of this disorder. Although many different opinions are advanced regarding the etiology of the disease, the outstanding ones are those postulating a faulty bone marrow or an increase in hemolysin production. The theory of faulty bone marrow production, as introduced by Naegeli (1), claims that spherocytes are produced by the bone marrow and that splenectomy does not change the production of abnormal red cells. The dramatic effect of this operation is explained by removal of the inhibitory effect of the spleen on the bone marrow (1). Careful studies of the hemoglobin metabolism in this disorder, however, have revealed that, after splenectomy, increased blood destruction (as measured by the urobilinogen output) and also increased erythrocyte production (as evaluated by the reticulocyte counts) return to normal values despite the continued presence of spherocytes. Some observers (2) believe that the spleen is the most important organ in this disease but do not deny production of spherocytes by the bone marrow.

The hemolysin theory, on the other hand, states that the shape of the red cells is altered outside the bone marrow through the action of hemolysins. Dameshek and Schwartz (3) produced spherocytosis in experimental animals by the injection of specific hemolytic sera and Haden (4) was able to induce the same abnormality in vitro by the addition of hypotonic saline solutions to normal erythrocytes. The former authors have

1 This work has been aided by grants from the Milton fund of Harvard University and the Dazian Foundation for Medical Research. interpreted spherocytosis as a precursor of hemolysis and the morphological expression of an alteration in the structure of erythrocytes due to the action of different types of hemolytic substances. Dameshek and Schwartz (3) demonstrated the presence of hemolysins of the immune body type in cases of acquired hemolytic anemia and showed the disappearance of these antibodies and of spherocytosis after splenectomy. In congenital hemolytic anemia, however, the demonstration of hemolysins has not been consistently made. Recently, Bergenhem and Fåhraeus (5) showed the presence in normal blood serum of a hitherto unknown hemolytic substance called lysolecithin. They postulated that an increase in the production of this lysin might be the cause of congenital hemolytic anemia. Singer (6) demonstrated the increased fragility of spherocytes present in the congenital condition towards this lysin but found that spherocytes from cases of acquired hemolytic anemia reacted like normal cells. These findings have recently been confirmed by Gripwall (2). The present paper deals with the problem of lysolecithin production in the body and the possible relationship of this physiological lysin to the development of congenital hemolytic jaundice.

THE RESEARCHES OF BERGENHEM AND FÅHRAEUS

Bergenhem and Fåhraeus (5) were led to the discovery of their lysolecithin by observing characteristic changes in blood which was allowed to stand quietly for several hours at body temperature. This incubated blood showed considerable retardation of the sedimentation rate of the erythrocytes, a change in the shape of red cells from the biconcave to the spherical form and a noticeable reduction of aggregation (rouleaux formation). These authors demonstrated that these changes were due to the action of a substance 
formed by an enzyme which was capable of splitting this substance from the serum lipoids. Adsorption of the latter substance by the red blood cells resulted in the above alterations. If stronger concentrations of this substance developed, actual hemolysis of the erythrocytes was noted. The enzymatic process in the serum reached its maximum at a temperature of $42^{\circ} \mathrm{C}$. and $\mathrm{a} \mathrm{pH}$ of 7.2 and was inactivated at $56^{\circ} \mathrm{C}$. Bergenhem and Fåhraeus (5) concluded that this hemolytic substance was either identical with the so-called lysolecithin or very closely related to it.

Lysolecithin is a definite chemical substance ${ }^{2}$ which has previously received attention in the study of the biological effect of snake venom. From the investigations of Flexner and Noguchi (8), Kyes and Sachs (9), Luedecke (10), Manwaring (11), Delezenne and Ledebt (12), it is known that cobra toxin hemolyzes red blood cells only in the presence of serum and that the blood lipoids are necessary for this hemolytic activity. Snake venom also contains a lecithinase which changes lecithin to lysolecithin, the latter having hemolytic qualities. Small amounts of lysolecithin obtained by the action of cobra toxin on lecithin, when added to normal blood, produce the same changes as the substance obtained from incubated serum. If normal serum is inactivated, and cobra toxin then added, the hemolytic power of the serum extract can be reestablished. Formation of lysolecithin by the lecithinases present in cobra toxin and in normal serum can be prevented by adding quinine which is a typical inhibitor of the action of lipases.

Recent investigations by Bergenhem (7) have revealed certain other qualities of lysolecithin. This author pointed out that lysolecithin is in some manner related to the complement function of the serum and that there are several parallelisms in the behavior of this lysin and of complement which are of particular interest. It has been known for many years that such manipulations as shaking of the serum, dilution with distilled water, etc. may destroy or inactivate the complement function ( $c f$. Sachs and Klopstock (13)). Ber-

\footnotetext{
2 Lysokephalin is supposed to have quite similar qualities. Both lysolecithin and lysokephalin are sometimes called lysocithin (7).
}

genhem and Fåhraeus (5) demonstrated that lysolecithin is also destroyed or rendered inactive by shaking or moving the serum. The most interesting phenomenon was the demonstration that the lysolecithin content present in a freshly drawn blood sample can be increased if the unmoved serum is incubated for several hours; if, however, the serum is kept in motion during incubation, this increase does not occur. Since circulating blood is under conditions of constant motion, it is to be expected that the amount of lysolecithin present in the circulating blood must be smaller than in blood which is stagnant.

Bergenhem and Fåhraeus (5) believe that lysolecithin may be of great importance in the physiological mechanism of erythrocyte destruction. They point out that the spleen must be considered as an organ containing a more or less constant reservoir of blood, as shown by the wellknown researches of Barcroft (14) and his associates. Blood stored in the spleen is temporarily excluded from the circulation, and in this splenic reservoir an increased formation of lysolecithin may occur. By adsorption of this substance by the erythrocytes, direct hemolysis of the red blood corpuscles in the spleen, or preparation of these erythrocytes for further destruction, presumably takes place. In hemolytic jaundice, where the enlarged spleen contains large quantities of blood, an increased production of lysolecithin is said to occur and is held to be responsible for the increased erythrocyte destruction. For lack of a biological micromethod for determination of lysolecithin, Bergenhem and Fåhraeus (5) were unable to carry out direct measurements of this substance in blood. They therefore worked with large quantities of horse serum, measuring changes in the red cells by means of the sedimentation rate. As changes in the sedimentation rate are frequently slight and difficult to evaluate, a simpler and more accurate method for determination of lysolecithin appeared desirable. In another paper (6) a method for determination of the lysolecithin fragility of various red cells (normal and spherocytic) was described. By adaptation of this method the problem of the significance of lysolecithin in the mechanism of hemolysis in physiological and pathological conditions was facilitated. 


\section{METHODS}

In the paper (6) on the lysolecithin fragility test, a method for extraction of this lysin from serum was described. This method has been adapted for the quantitative determination of the lysolecithin content of serum. Blood is drawn and put into the ice chest until it is completely clotted and the serum is expressed. Then the serum is removed from the clot by means of a capillary pipette. Usually, the obtained serum is centrifuged in order to remove the last vestiges of erythrocytes. It was noted that the process of centrifuging the serum for several minutes apparently does not diminish the content of lysolecithin. The serum, which is now completely freed from any erythrocytes, is then divided into two equal parts. One part is precipitated immediately by means of alcohol, the other part after incubation. Ten cc. of blood serum are precipitated with 10 times its quantity of 95 per cent alcohol, filtered, and the filtrate evaporated in a vacuum apparatus at room temperature to complete dryness. The residue is again dissolved in 5 cc. alcohol, filtered, mixed with 6 times its quantity of ether, and placed in the refrigerator overnight. The precipitate contains the lysolecithin. After centrifugation the ether is removed by means of a suction pump, and after the precipitate is dried the content of lysolecithin is determined. For this determination its hemolytic power is used. The dried precipitate is now dissolved in $0.8 \mathrm{cc}$. of physiological salt solution. From this basic solution a geometric series of dilutions is prepared in the usual manner by further dilution with saline. An approximate 2 per cent saline suspension of washed erythrocytes ${ }^{3}$ (containing about 100,000 cells per cmm.) is taken up in leukocyte pipettes to the 1 mark and diluted with the various single dilutions of lysolecithin to the 11 mark. While hemolysis is taking place, the pipettes are set aside for one hour; with very weak concentrations of the lysin present, the reaction may be facilitated by placing the pipettes in the incubator for the same period. The solutions are then examined in a hematocytometer. By determining the number of undissolved erythrocytes, an exact measure of the degree of hemolysis is obtained. Hemolysis above 90 per cent is regarded as complete. At this degree of hemolysis the opaque fluid in the pipettes becomes clear and transparent. The lysolecithin content of a serum is expressed in the hemolyzing value of the substance derived from $10 \mathrm{cc}$. of serum. Only the solutions which give complete hemolysis are considered for the evaluation.

As already mentioned, Bergenhem and Fåhraeus (5) found that the lysolecithin content of a serum

3 The erythrocyte suspension is usually made of the patient's own red cells, but it is also possible to use other normal erythrocytes as there is practically no difference in the lysolecithin fragility of the erythrocytes of normal persons. These erythrocytes are obtained from oxalated blood and are then washed three times with normal saline before suspension is prepared. can be increased if unmoved blood is incubated for from 8 to 24 hours, but that this increase does not take place if blood is moved during the incubation period. As an example, Table I shows the results of determination in the lysolecithin content of 2 aliquot samples of unincubated and incubated serum in 2 different dogs and also the results of movement during the whole incubation period.

TABLE I

Lysolecithin content of unincubated and incubated serum

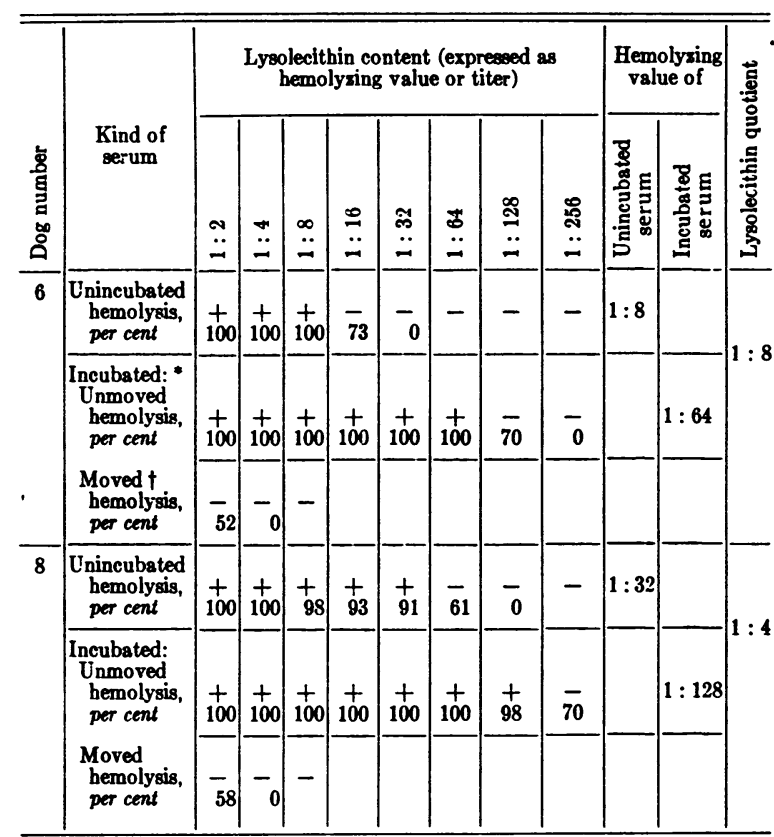

* Time of incubation was 20 to 24 hours.

t Shaking of the serum was performed by means of a motor twice a minute.

These experiments confirm the statement of Bergenhem and Fåhraeus (5). In determining the relationship between the lysolecithin content of 2 equal amounts of unincubated and incubated blood of the same blood sample, we should be able to differentiate between stagnant (i.e. unmoved) and circulating (i.e. moved) blood. In stagnant blood we can expect that the lysolecithin content of the unincubated blood sample must be much higher compared with the corresponding value in circulating blood, because this blood reacts like the blood sample in the incubator. The relationship of the lysolecithin content in equal amounts of unincubated and incubated unmoved blood of 
the same sample is called the lysolecithin quotient (LLQ) :

Lysolecithin content of unincubated serum

Lysolecithin content of incubated serum

$$
=\mathrm{LLQ} \text {. }
$$

In stagnant blood we should find a LLQ of 1 or approaching 1 , in contradistinction to circulating blood where the LLQ must be smaller due to the fact that the amount of lysolecithin can be increased by incubation. In stagnant or stored blood this incubation has already taken place in the body. In the following experiments the LLQ was always determined from $10 \mathrm{cc}$. of serum. To use smaller quantities of serum, the method has been further modified: the test is made in special pipettes that take just half of the content of normal leukocyte pipettes. The amount of serum used for each determination can thus be reduced to $5 \mathrm{cc}$; the dried lysolecithin for each evaluation is dissolved in $0.4 \mathrm{cc}$. instead of $0.8 \mathrm{cc}$. of normal salt solution.

\section{RESULTS}

\section{A. The LLQ of peripheral blood in normal conditions}

The LLQ was determined in 8 dogs and 30 normal human beings. The normal group comprised healthy physicians, students and patients who showed no evidence of liver, spleen, or blood disease or of any condition in which an abnormally lowered velocity of blood flow was suspected. Table II contains the values obtained in 10 human beings and the first column of Table III shows the results in dogs. For simplification, only the end results of the determinations are given. The lysolecithin content of dog serum was tested against dog erythrocytes, but for the determination of lysolecithin in human serum, human erythrocytes were used. The hemolytic titer of dog serum is apparently greater than that of human serum, although this may simply be due to the greater fragility of the red cells of the dog to lysolecithin. Normally the LLQ is always a fraction of 1 , the lysolecithin content (expressed in hemolytic titer) of the incubated serum being 2 to 8 times greater than that of the unincubated serum. Relatively great differences were encountered in different individuals. In human beings only venous blood was used for the determinations. In dogs no difference was demonstrated in the LLQ of arterial as against venous blood of the same animal, but rather considerable individual differences were present. The LLQ in the 8 dogs was always $1 / 4$ to $1 / 8$.

TABLE II

LLQ in normal human blood

\begin{tabular}{c|c|c|c}
\hline \multirow{2}{*}{ Number } & \multicolumn{2}{|c|}{ Lysolecithin content of serum } & \multicolumn{1}{c}{ LLQ } \\
\cline { 2 - 3 } & Unincubated & Incubated & \\
\hline 1 & $1: 2$ & $1: 8$ & $2: 8=1 / 1 / 4$ \\
2 & $1: 4$ & $1: 8$ & $4: 8=1 / 2$ \\
3 & $1: 4$ & $1: 16$ & $4: 16=1 / 4$ \\
4 & $1: 8$ & $1: 16$ & $8: 16=1 / 2$ \\
5 & $1: 2$ & $1: 16$ & $2: 16=1 / 8$ \\
6 & $1: 4$ & $1: 16$ & $4: 16=1 / 4$ \\
7 & $1: 4$ & $1: 32$ & $4: 32=1 / 8$ \\
8 & $1: 4$ & $1: 8$ & $4: 8=1 / 2$ \\
9 & $1: 8$ & $1: 16$ & $8: 16=1 / 2$ \\
10 & $1: 2$ & $1: 16$ & $2: 16=1 / 8$ \\
& & & \\
\hline
\end{tabular}

\section{B. The LLQ in splenic vein blood (stored blood)}

Determinations of the LLQs in blood obtained from the splenic artery and vein were performed in 8 dogs in order to show possible differences between the "reservoir blood" of the spleen and that of the circulating peripheral blood. Due to the great difficulties in obtaining sufficient amounts of reservoir blood directly from the spleen, determinations in the splenic vein blood were made because it was thought that the splenic vein might not only contain blood passing directly through this organ, but also a more or less large quantity of stored blood. The results are tabulated in column 2 of Table III.

In all experiments the LLQ in the splenic vein blood was greater than that in the splenic artery (i.e., following incubation of splenic vein blood there was usually no increase in lysolecithin titer). In 6 of the 8 experimental animals the unincubated blood of the splenic vein contained as much lysolecithin as the incubated; the LLQ was 1 . In 2 animals the lysolecithin content of the unincubated sample was not an optimal one and could still be increased by. incubation. But compared with the corresponding arterial blood, a higher lysolecithin content was observed in these 2 dogs as well. In order to decide whether the erythrocytes coming from the stored blood of the 
TABLE III

LLQ in dog serum

\begin{tabular}{|c|c|c|c|c|c|c|c|c|c|}
\hline \multirow{3}{*}{$\underset{\text { ber }}{\operatorname{Dog}}$} & \multicolumn{9}{|c|}{ Lysolecithin content in serum from } \\
\hline & \multicolumn{3}{|c|}{ Peripheral blood* } & \multicolumn{3}{|c|}{ Splenic vein blood } & \multicolumn{3}{|c|}{ Hepatic vein blood $\dagger$} \\
\hline & $\begin{array}{c}\text { Un- } \\
\text { incu- } \\
\text { bated }\end{array}$ & $\begin{array}{l}\text { Incu- } \\
\text { bated }\end{array}$ & LLQ & $\begin{array}{c}\text { Un- } \\
\text { incu- } \\
\text { bated }\end{array}$ & $\underset{\text { bated }}{\text { Incu- }}$ & LLQ & $\begin{array}{c}\text { Un- } \\
\text { incu- } \\
\text { bated }\end{array}$ & $\begin{array}{l}\text { Incu- } \\
\text { bated }\end{array}$ & LLQ \\
\hline $\begin{array}{l}1 \\
2 \\
3 \\
4 \\
5 \\
6 \\
7 \\
8\end{array}$ & $\begin{array}{l}1: 8 \\
1: 8 \\
1: 16 \\
1: 16 \\
1: 8 \\
1: 8 \\
1: 32 \\
1: 32\end{array}$ & $\begin{array}{l}1: 64 \\
1: 32 \\
1: 64 \\
1: 64 \\
1: 64 \\
1: 64 \\
1: 128 \\
1: 128\end{array}$ & $\begin{array}{l}1 / 8 \\
1 / 4 \\
1 / 4 \\
1 / 4 \\
118 \\
1 / 8 \\
1 / 4 \\
1 / 4\end{array}$ & $\begin{array}{l}1: 64 \\
1: 32 \\
1: 64 \\
1: 64 \\
1: 64 \\
1: 64 \\
1: 64 \\
1: 64\end{array}$ & $\begin{array}{l}1: 64 \\
1: 32 \\
1: 64 \\
1: 64 \\
1: 64 \\
1: 64 \\
1: 128 \\
1: 128\end{array}$ & $\begin{array}{c}1 \\
1 \\
1 \\
1 \\
1 \\
1 \\
1 / 2 \\
1 / 2\end{array}$ & $\begin{array}{c}1: 8 \\
\text { not d } \\
\text { not d } \\
\text { not d } \\
\text { not d } \\
1: 8 \mid \\
\text { not d } \\
1: 32\end{array}$ & $\begin{array}{l}1: 64 \\
\text { leterm } \\
\text { determ } \\
\text { determ } \\
\text { leterm } \\
1: 64 \\
\text { leterm } \\
1: 128\end{array}$ & $\begin{array}{r}1 / 8 \\
\text { ined } \\
\text { lined } \\
\text { lined } \\
\text { ined } \\
1 / 8 \\
\text { ined } \\
1 / 4\end{array}$ \\
\hline
\end{tabular}

* Peripheral blood was drawn from jugular vein or carotid artery.

† Hepatic vein blood was obtained after preceding ligature of inferior vena cava.

spleen might have already adsorbed lysolecithin with a resultant tendency to spherocytosis and increased fragility, the lysolecithin fragility of red cells from the splenic vein and the splenic artery was compared. Bergenhem and Fåhraeus (5) noted such a tendency, and Heilmeyer (15) found by direct measurement of the thickness of the red cells from the splenic artery and the splenic vein in patients with hemolytic anemia that the splenic vein erythrocytes were considerably thicker. Such a tendency should lead to increased fragility. Table IV (as an example of numerous experiments) shows, however, that no difference in the lysolecithin fragility of the erythrocytes in both splenic vessels could be demonstrated. In order to test the lysolecithin fragility, 2 exactly equal suspensions of erythrocytes from the splenic artery and the splenic vein $(100,000$ cells per cmm.) were tested against 2 exactly equal concentrations of a lysolecithin extract.

TABLE IV

Lysolecithin fragility of splenic artery and splenic vein erythrocytes

\begin{tabular}{c|c|c|c|c|c|c}
\hline \hline \multirow{2}{*}{ Kind of erythrocytes } & \multicolumn{5}{|c}{ Lysolecithin dilutions } \\
\cline { 2 - 5 } & $1: 2$ & $1: 4$ & $1: 8$ & $1: 16$ & $1: 32$ & $1: 64$ \\
\hline $\begin{array}{c}\text { From artery: hemolysis, } \\
\text { per cent }\end{array}$ & + & + & + & + & - & \\
$\begin{array}{c}\text { From vein: hemolysis, } \\
\text { per cent }\end{array}$ & 100 & 100 & 100 & 94 & 38 & 0 \\
\hline
\end{tabular}

\section{The $L L Q$ in hepatic vein blood}

To decide whether blood coming from other blood reservoirs than the spleen might show the same changes, the LLQ in hepatic vein blood obtained after ligature of the inferior vena cava was determined in 3 dogs (Table II, column 3 ). Some investigators $(16,17)$ believe that not only the spleen but also the liver may be regarded as an organ containing more or less large blood depots. In contradistinction to the splenic vein blood, hepatic venous blood showed the same LLQ as found in the peripheral circulation.

\section{The $L L Q$ in the blood of varicose veins}

As already pointed out, a LLQ of 1 may, under certain conditions, demonstrate the presence of stagnant blood, or at least of a very sluggish circulation. To confirm this interpretation, the LLQ was determined in other conditions in which the presence of a sluggish circulation of blood might be assumed. Following a suggestion by $\mathrm{Dr}$.

TABLE V

The LLQ in varicose vein blood

\begin{tabular}{c|c|c|c|c|c|c}
\hline \hline & \multicolumn{4}{|c|}{ Lysolecithin content in serum from } \\
\cline { 2 - 7 } $\begin{array}{c}\text { Case } \\
\text { number }\end{array}$ & \multicolumn{2}{|c|}{ Cubital vein blood } & \multicolumn{3}{|c}{ Varicose vein blood } \\
\cline { 2 - 6 } & $\begin{array}{c}\text { Unincu- } \\
\text { bated }\end{array}$ & $\begin{array}{c}\text { Incu- } \\
\text { bated }\end{array}$ & LLQ & $\begin{array}{c}\text { Unincu- } \\
\text { bated }\end{array}$ & $\begin{array}{c}\text { Incu- } \\
\text { bated }\end{array}$ & LLQ \\
\hline 1 & $1: 8$ & $1: 16$ & $1 / 2$ & $1: 16$ & $1: 16$ & 1 \\
2 & $1: 8$ & $1: 16$ & $1 / 2$ & $1: 16$ & $1: 16$ & 1 \\
3 & $1: 8$ & $1: 16$ & $1 / 2$ & $1: 16$ & $1: 16$ & 1 \\
4 & $1: 8$ & $1: 16$ & $1 / 2$ & $1: 16$ & $1: 16$ & 1 \\
5 & $1: 4$ & $1: 16$ & $1 / 4$ & $1: 16$ & $1: 16$ & 1 \\
6 & $1: 2$ & $1: 8$ & $1 / 4$ & $1: 8$ & $1: 8$ & 1 \\
7 & $1: 4$ & $1: 8$ & $1 / 2$ & $1: 4$ & $1: 8$ & $1 / 2$ \\
\hline
\end{tabular}

Robert Brandt of Augusta, Georgia, determinations of the LLQ in blood from varicose veins were performed. The investigations of Magnus (18) have shown that the blood in large varicose veins possesses a very sluggish circulation, particularly when the patient is in a horizontal position. Nobel (19) and Wolf and Remenovsky (20) demonstrated this tendency to stagnation by $x$-ray studies of the injected veins. In $6 \mathrm{pa-}$ tients with very large varicose veins the LLQ in blood from the cubital vein and in blood from the varicose vein was compared. Blood was taken in the morning before the patient got up. Table V 
shows that blood obtained from the varicose veins always presented a LLQ of 1 in contradistinction to blood from the cubital veins. Case 7 shows identical values for blood of the upper and lower extremities; no varices were present and this case was taken as a control.

\section{E. The $L L Q$ in cases of congenital hemolytic anemia}

According to the hypothesis of Bergenhem and Fåhraeus (5), lysolecithin may be considered to be the lysin responsible for the spherocytosis and increased blood destruction in this disorder. It seemed, therefore, of great interest to determine the LLQ in such cases. Table VI shows the results obtained in 6 cases of congenital hemolytic jaundice.

TABLE VI

The $L L Q$ in cases of hemolytic jaundice

\begin{tabular}{|c|c|c|c|c|}
\hline \multirow{2}{*}{$\begin{array}{c}\text { Case } \\
\text { num- } \\
\text { ber }\end{array}$} & \multirow{2}{*}{ State of blood } & \multicolumn{3}{|c|}{$\begin{array}{l}\text { Lysolecithin content of } \\
\text { serum* from }\end{array}$} \\
\hline & & $\begin{array}{l}\text { Unincu- } \\
\text { bated } \\
\text { blood }\end{array}$ & $\begin{array}{l}\text { Incu- } \\
\text { bated } \\
\text { blood }\end{array}$ & LLQ \\
\hline 1 & $\begin{array}{lc}\text { Hemoglobin } & 50 \% \\
\text { Erythrocytes } & 2,500,000 \\
\text { Reticulocytes } & 9 \%\end{array}$ & $1: 1$ & $1: 16$ & $1 / 16$ \\
\hline 2 & $\begin{array}{lc}\text { Hemoglobin } & 54 \% \\
\text { Erythrocytes } & 3,000,000 \\
\text { Reticulocytes } & 7.8 \%\end{array}$ & $1: 8$ & $1: 16$ & $1 / 2$ \\
\hline 3 & $\begin{array}{lc}\text { Hemoglobin } & 90 \% \\
\text { Erythrocytes } & 4,200,000 \\
\text { Reticulocytes } & 8.4 \%\end{array}$ & $1: 2$ & 1: 4 & $1 / 2$ \\
\hline 4 & $\begin{array}{ll}\text { Hemoglobin } & 64 \% \\
\text { Erythrocytes } & 3,600,000 \\
\text { Reticulocytes } & 8.2 \%\end{array}$ & $1: 4$ & 1: 8 & $1 / 2$ \\
\hline 5 & $\begin{array}{lc}\text { Hemoglobin } & 70 \% \\
\text { Erythrocytes } & 3,600,000 \\
\text { Reticulocytes } & 18 \%\end{array}$ & $1: 4$ & 1:16 & $1 / 4$ \\
\hline 6 & $\begin{array}{ll}\text { Hemoglobin } & 106 \% \\
\text { Erythrocytes } & 4,900,000 \\
\text { Reticulocytes } & 7.2 \%\end{array}$ & $1: 8$ & 1:16 & $1 / 2$ \\
\hline
\end{tabular}
fossa.

* Blood was obtained from the vein of the antecubital

In all cases the saline fragility of the erythrocytes was increased and the lysolecithin fragility test was likewise pathological. The evaluation of the lysolecithin content was performed with normal erythrocytes in order to avoid errors which might be caused by the increased susceptibility of the patient's own erythrocytes. As demonstrated in another paper (6a), the spherocytes of congenital hemolytic jaundice have a decreased resistence towards lysolecithin and therefore give higher hemolyzing values. All these cases show no great difference from the normal cases as far as the lysolecithin content of the serum is concerned. Only Case 1 had a very low value in the unincubated blood. In no case was there any evidence indicating an increased production of lysolecithin.

\section{DISCUSSION}

The results thus far obtained have confirmed the findings of Bergenhem and Fåhraeus (5) regarding lysolecithin. The demonstration has furthermore been made that the concentration of this physiological lysin is increased by keeping the serum quietly in the incubator for several hours; no such increase occurs in serum which has been shaken. This increase in the amount of lysolecithin in incubated serum may be expressed by the lysolecithin quotient, in which the relationship of the lysolecithin content of unincubated to that of incubated (unmoved) serum of the same blood sample is determined.

In circulating blood this quotient is always a fraction of 1 . In stagnant blood the LLQ is 1 or approximates 1 , probably because the enzymatic process causing an increase in lysolecithin in the incubated test tube has already been active within the body. In splenic vein blood of dogs the LLQ was found to be 1 in most animals, probably due to storage of blood in the spleen. At least from the standpoint of lysolecithin production, the spleen may be considered to be the "incubator" of the body. That a LLQ of 1 is the serological manifestation of stagnant blood was also indicated in investigations of blood obtained from varicose veins. The extremely sluggish circulation in these veins, particularly in patients placed in a horizontal position for several hours, has been demonstrated by Magnus (18), Nobel (19) and others (20). The finding of a LLQ of 1 in blood from these veins in contradistinction to a LLQ of $1 / 8$, $1 / 4$, etc. in blood obtained from the cubital vein in the same patient supports the interpretation suggested in this paper.

The concept of Rein (16) and associates, Ep- 
pinger (17), and others, that the liver may also be regarded as an organ containing blood depots, could not be corroborated by determining the LLQ. The finding of a normal LLQ in the hepatic veins may be explained either by the assumption that no "storage" blood was obtained in our experiments, or that the mechanism of storage of the blood in the liver may be quite different from that in the spleen. The recent investigations of Knisely (21) on the histology of the spleen indicate that the red cells are separated from the fluid of the blood in the venous sinuses of the spleen. As a LLQ of 1 was obtained from serum of the splenic vein blood in 6 of 8 examined animals, we may conclude that not only the erythrocytes but also the plasma must be stored in the spleen for the reason that only unmoved serum gives a LLQ of 1 . Due to this storage the "reservoir blood" of the spleen probably has an increased content of lysolecithin.

Although these experiments confirm the hypothesis of Bergenhem and Fåhraeus (5) that splenic reservoir blood contains more lysolecithin than circulating blood, there is at present no proof for the assumption that, since this substance has hemolytic power when extracted from the serum, it is therefore actively engaged in normal blood destruction. It is also very doubtful whether the concentration of lysolecithin obtainable from serum may be considered sufficient for the range of normal blood destruction in the body. The recently published experiments of Ham and Castle (22), who believe that splenic hemolysis is due to metabolic changes of the erythrocytes produced by intravascular stasis, likewise rule out any action of lysolecithin in this mechanism. Furthermore, lysolecithin can by no means be regarded as the lysin primarily responsible for the hematological changes in congenital hemolytic jaundice. According to the hemolysin theory, spherocytosis is produced outside of the bone marrow by action of hemolysins upon normal red cells. It is the morphological expression of an alteration in the physical-chemical structure of erythrocytes. Although in a previous communication (6a) demonstration was made that the lysolecithin fragility of spherocytes in congenital hemolytic jaundice is remarkably increased compared with that of normal cells, the lysolecithin production in the pe- ripheral blood in that disorder was found to be normal. ${ }^{4}$ In order to explain the presence of spherocytosis and greatly increased blood destruction regularly seen in congenital hemolytic jaundice, Bergenhem and Fåhraeus (5) assumed an increased production of lysolecithin. The findings of both normal content and quotient appear to rule out the lysolecithin as of any significance in the pathogenesis of this disease. We believe, therefore, that lysolecithin, although it has hemolytic qualities, is not the hemolysin responsible for the production of hemolytic jaundice.

\section{SUMMARY}

1. Bergenhem and Fåhraeus demonstrated that normal blood contains a hemolyzing substance called lysolecithin. They believed that this lysin was developed in high concentration in the stored blood of the spleen and was therefore involved in the physiological mechanism of blood destruction. Congenital hemolytic jaundice was assumed to be due to an increased production of this substance.

2. A quantitative method is described for determination of the lysolecithin content in relatively small amounts of blood. The content of lysolecithin in peripheral blood of dogs and normal human beings was determined. It was demonstrated that this content could be increased 2 to 8 times by incubating unmoved blood for several hours, but that moving the blood during incubation did not produce this increase, probably due to the fact that moving destroyed or inactivated the lysin. Circulating (i.e. moved) blood contains less lysolecithin than stagnant (i.e. unmoved) blood. To relate circulation of blood to its lysolecithin production the lysolecithin quotient $L L Q=$

Lysolecithin content of unincubated serum Lysolecithin content of incubated serum was determined.

3. The LLQ of normal peripheral blood is always a fraction of 1 ; in stagnant or stored blood the LLQ was found to be 1 . By means of the LLQ, the differentiation between circulating and stagnant blood appears possible.

4 Unfortunately, no data concerning the lysolecithin production in splenic artery and splenic vein blood in cases of hemolytic jaundice are yet available, although such investigations would be highly desirable. 
4. Blood from the splenic vein in dogs has a LLQ of 1, indicating the presence of stored blood coming from the spleen. The LLQ in blood from the splenic artery, however, was always a fraction of 1 . These findings demonstrate an increased lysolecithin production in the "splenic reservoir blood."

5. The LLQ obtained from blood from varicose veins, presenting an area of very sluggish circulation, was likewise 1.

6. The LLQ in blood from the hepatic vein was the same as in peripheral blood. This finding might indicate that the mechanism of "storage of blood" in the liver might be different from that in the spleen, where, presumably, separation of plasma and erythrocytes inside the organ occurs (21).

7. No difference in the lysolecithin content and the LLQ in the blood of patients with congenital hemolytic anemia, as compared with that of normal persons, was found.

8. The significance of lysolecithin as the physiological hemolysin involved in the mechanism of normal blood destruction by increased production in splenic reservoir blood is not conclusive. It is also very unlikely that lysolecithin can be regarded as responsible for the increased blood destruction in congenital hemolytic jaundice, since no increase in the production of this lysin was demonstrable in the disease. It is therefore believed that lysolecithin, although having hemolytic qualities, is not the hemolysin causing hemolytic anemia.

\section{BIBLIOGRAPHY}

1. Naegeli, O., Blutkrankheiten und Blutdiagnostik. Springer, Berlin, 1931.

2. Gripwall, E., Zur Klinik und Pathologie des hereditären hemolytischen Ikterus mit besonderer Berüksichtigung des Verhaltens der roten Blutkörperchen. Acta Med. Scandinav., 1938, Supp. 96, 1.

3. Dameshek, W., and Schwartz, S. O., Hemolysins as the cause of clinical and experimental hemolytic anemias, with particular reference to nature of spherocytosis and increased fragility. Am. J. M. Sc., 1938, 196, 769.

4. Haden, R. L., The mechanism of the increased fragility of the erythrocytes in congenital hemolytic jaundice. Am. J. M. Sc., 1934, 188, 441.

5. Bergenhem, B., and Fåhraeus, R., Ueber spontane Hemolysinbildung im Blut unter besonderer Be- ruecksichtigung der Physiologie der Milz. Ztschr. f. d. ges. exper. Med., 1936, 97, 555.

6a. Singer, K., The lysolecithin fragility test. Am. J. M. Sc., 1940, 199, 466.

b. Singer, K., Das Problem der normalen und pathologischen Milzhaemolyse. (Lecture November 4, 1937, Gesellschaft fuer Innere Medizin, Vienna.) Wien. Arch. f. Inn. Med., 1937, 37, 161. (Gesellschaftsberichte.)

7. Bergenhem, B., Experimentelle Untersuchungen ueber die spontanen Veränderungen des Blutes in vitro hinsichtlich Suspensionsstabilität Komplementaktivität und Antithrombinfunktion. Acta Path. et Microbiol. Scandinav., 1939, Supp. 39, 1.

8. Flexner, S., and Noguchi, H., Snake venom in relation to hemolysis, bacteriolysis and toxicity. J. Exper. Med., 1902, 6, 277.

9. Kyes, P., and Sachs, H., Zur Kenntnis der Cobragifte aktivierenden Substanzen. Klin. Wchnschr., $1903,57,82$.

10. Luedecke, K., Quoted by Bergenhem and Fåhraeus.

11. Manwaring, W. H., Ueber die Lecithinase des Kobragiftes. Ztschrft. Immun. Forschg., 1910, 6, 513.

12. Delezenne, C., and Ledebt, S., Action du venin de cobra sur les serums de cheval. Compt. Rendus Acad de Sci. Paris, 1911, 152, 790.

13. Sachs, H., and Klopstock, A., Methoden der Hemolyseforschung. Urban and Schwarzenberg, Berlin, 1928.

14. Barcroft, J., Stellung der Milz in Kreislaufsystem. Erg. Physiol., 1926, 25, 818.

15a. Heilmeyer, L., and Albus, L., Die hemolytische $\mathrm{Hy}$ persplenie. Deutsches Arch. f. klin. 'Med., 1936, $178,89$.

b. Heilmeyer, L., Die Sphårocytose als Ausdruck einer pathologischen Funktion der Milz. Deutsches Arch. f. klin. Med., 1936, 179, 292.

16. Rein, H., Die Blutreservoire des Menschen. Klin. Wchnschr., 1933, 12, 1.

17. Eppinger, H., Die Leberkrankheiten. Springer, Vienna, 1937.

18. Magnus, G., Zirkulationsverhältnisse in Varicen. D. Ztschrft. f. Chirurgie., 1921, 162, 71.

19. Nobel, G., Quoted by Wolf and Remenovsky.

20. Wolf, M., and Remenovsky, F., Praktische Anwendung der Varicographie. Klin. Wchnschr., 1931, 44, 353.

21. Knisely, M. H., Spleen Studies. I. Microscopic observations of circulatory system of living unstimulated mammalian spleens. Anat. Rec., 1936, 65, 23. II. Microscopic observations of circulatory system of living traumatized spleens and of dying spleens. Ibid, 131.

22. Ham, T. H., and Castle, W. B., Relation of increased hypotonic fragility and erythrostasis to the mechanism of hemolysis in certain anemias. Proc. Am. Philosoph. Soc., 1940, 82, 411. 